Long Island University

Digital Commons@ @IU

Post Library Faculty Publications

Library

$1-29-2015$

\title{
Using the Flipped Classroom Model in Your Library Instruction Course
}

Eduardo Rivera Jr

Long Island University, eduardo.rivera@liu.edu

Follow this and additional works at: http://digitalcommons.liu.edu/post_libfacpubs

Part of the Information Literacy Commons

\section{Recommended Citation}

Rivera, Eduardo Jr, "Using the Flipped Classroom Model in Your Library Instruction Course" (2015). Post Library Faculty Publications. 10.

http://digitalcommons.liu.edu/post_libfacpubs/10

This Article is brought to you for free and open access by the Library at Digital Commons @ LIU. It has been accepted for inclusion in Post Library Faculty Publications by an authorized administrator of Digital Commons @ LIU. For more information, please contact natalia.tomlin@liu.edu. 


\section{Using the Flipped Classroom Model in Your Library Instruction Course}

\section{Eduardo Rivera}

To cite this article: Eduardo Rivera (2015) Using the Flipped Classroom Model in Your Library Instruction Course, The Reference Librarian, 56:1, 34-41, DOI: 10.1080/02763877.2015.977671

To link to this article: http://dx.doi.org/10.1080/02763877.2015.977671

曲 Published online: 29 Jan 2015.

Submit your article to this journal $\widetilde{ }$

山 Article views: 641

Q View related articles $\longleftarrow$

View Crossmark data ¿

Citing articles: 2 View citing articles $\sqsubset$ 


\title{
Using the Flipped Classroom Model in Your Library Instruction Course
}

\author{
EDUARDO RIVERA \\ B. Davis Schwartz Memorial Library, LIU Post, Brookville, NY
}

\begin{abstract}
In the flipped classroom model, the pedagogical paradigm is reversed and the students learn the class lesson at bome and do bomework in class. Although much of the focus of the flipped model has been on the secondary education level, this model could be a viable way to teach library instruction sessions to college-level students as well as a way to preserve scarce class time. This article examines a project that was done at LIU Post, where an instructor of the Library Competency Workshop course flipped the classroom and compared test results to sections where the class was run in a traditional lecture classroom model as well as the experiences on bow the instructor flipped the classroom.
\end{abstract}

KEYWORDS flipped classrooms, information literacy, library instruction, teaching, teaching methods

\section{INTRODUCTION}

The idea of "flipping the classroom" has been gaining traction in recent years thanks to the great gains in technology to help support such a teaching style. In a flipped classroom, the students do traditional classwork at home (e.g., viewing a prerecorded version of the lesson) and complete homework in class, with the instructor present in order to assist the student and guide the practical application of the material. The thought behind this is that the class time is better used with the instructor there to assist and guide the students with the assignments as opposed to the students listening to the

(C) Eduardo Rivera

Address correspondence to Eduardo Rivera, B. Davis Schwartz Memorial Library, LIU Post, 720 Northern Boulevard, Brookville, NY 11548. E-mail: eduardo.rivera@liu.edu

Color versions of one or more of the figures in the article can be found online at www. tandfonline.com/wref. 
lecture in class and having no assistance with the assignments when they are being done out of class. As a result of the high-profile exposure of the Khan Academy, which has been featured on 60 Minutes and a prominent TED Talk by Khan Academy founder, Sal Khan (2011), and demand for studentcentered, flexible learning environments, the flipped class model is quickly moving to the forefront of current education trends and discussion.

\section{LITERATURE REVIEW}

The flipped class model has seen success at the secondary school level where it lends itself to certain subjects, such as science and math. The model is also conducive to the daily scheduling of classes on the K-12 level and the ability for instructors to interact with students every day. Jonathan Bergmann and Aaron Sams (2012) pioneered this model in their high school science classes initially out of necessity and, as they tell it, selfishness. They developed their flipped model as a way to save time so they did not need to cover material over and over again for those students who missed class. From there, it grew to be part of the regular class and it freed them up to use the class time to assist students with the application of the course material.

On the basis of the successes of Bergmann and Sams and Sal Khan and his Khan Academy, we developed a flipped library competency course at LIU Post. The course is a 7-week, non-credit-bearing workshop required for students to meet their information literacy competency requirement. It meets for 1 hour per week, making it extremely difficult to properly teach all of the material required in a basic level library research skills course. We recognized that a more effective approach would be to flip it, use short videos and tutorials for homework, and spend the class time practicing and using the research skills, with immediate instructor feedback and guidance.

At the college level, there is very little written on using the flipped classroom model. However, recent publications on using the flipped model for library instruction are growing. Most of the articles written on flipping information literacy classes assess student and instructor feedback using surveys and evaluations on the effectiveness of the flipped sessions, and the feedback on the flipped sessions is overwhelmingly positive. Lemmer (2013) wrote of the successes in using the "inverted classroom" in a very specific setting, for international students in a legal research class. Anonymous student course evaluations indicated $83.3 \%$ of the students strongly agreed that they would enjoy taking another course taught using the flipped classroom model. Similar results were reported in "Four Quick Flips" by Datig and Ruswick (2013). Their postclass assessments of integrated library instruction also indicated that students had very positive impressions about the sessions, including student replies that the sessions were "very helpful" and were a "creative approach to teaching." The Arnold-Garza study, "The Flipped Classroom: Assessing an Innovative Teaching Model for Effective 
and Engaging Library Instruction" (2014) found similar results. The study analyzed college-level flipped one-shot instruction requiring students to complete a preclass assignment of viewing videos and an exercise. Student questionnaires included responses such as "very helpful" and "It was a good experience over all," with 86\% of responses agreeing that they learned from the activities.

The literature provided the background information that students enjoyed the flipped class sessions and that the students felt that they learned more from those sessions. We wanted to find out whether those sentiments of the students on the flipped class sessions translated into increased scores on our Library Competency Exam.

\section{BACKGROUND}

\section{The Library Competency Requirement}

At our institution, every student must complete an information literacy library competency requirement to graduate. The students need to demonstrate that they can identify, locate, and evaluate information in an ethical and legal manner, as called for in the Association of College \& Research Libraries (ACRL) Information Literacy standards. This comes in the form of a library competency exam that every student must take. If they pass the exam, they fulfill the requirement. If students do not take the exam before their junior year, or if they do not pass the exam, then they must enroll in the Library Competency Workshop course.

\section{The Library Competency Workshop Course}

The course is a 7-week, non-credit-bearing course, taught by a library faculty member. Satisfactory completion of the course fulfills the students' Library Competency requirement. The course covers the basics of library research, in accordance with the ACRL Information Literacy Standards, such as finding books using the library's online catalog, finding periodical articles in online databases, and evaluating information sources and properly citing references. During the first session of the class, the students are given the Library Competency Exam and then take it again on the last meeting of the class to measure their progress after completing the seven week course.

\section{OBJECTIVES}

A common complaint among the teachers of the Library Competency Course is the lack of class time to properly cover the material with the students and the time to properly gauge their progress in the course. The course calls for a mere seven hours of instruction with the first and last class hours devoted to the students taking the pre- and posttest assessment, essentially 
reducing the course by two class sessions. Short of revamping the whole program, the library instructors have long sought out ways to improve the effectiveness and efficiency of the course so that it is meaningful to the students. It was proposed that the flipped classroom model may be a way to achieve this goal. By viewing the video modules, as homework, class time could be devoted to the students applying what was learned and the instructor providing remedial support. Flipping the library workshop course would perhaps result in improved and more meaningful learning, which would then lead to increased scores in the post test assessment.

\section{THE STUDY}

For the study, we wanted to experiment with video tutorials as a learning tool and to also make better use of the students' in-class time with the hopes of seeing an increase in post test scores. To do this, we used the flipped classroom model in two courses comparing test scores from both course sections that were not flipped to sections that were flipped. This was done with the same professor teaching the flipped and nonflipped sections.

\section{The Traditional Model}

Two Library Competency Workshop classes, one in the fall semester and the other in the spring semester, were taught in a traditional lecture style. Typically, 20 students are enrolled in each section but the actual number of students in each class varies as students drop the class or fail to show up. In those two sections, Fall Section 1 and Spring Section 2, the professor would lecture on the topic of the week, demo to the class using the Smart Classroom projector on topics such as searching the online library catalog or database usage. The class would then work on some in-class assignments, time permitting, and finish the rest for homework. This process was generally repeated for each session of the class.

The weekly breakdown of the course was as follows:

\section{Week Topic}

1. Introduction to Course, Pretest, Why do we need information (and this workshop)?

2. Catalog basics, Types of Books, Parts of a Book, Library Vocabulary

3. Call Numbers, Boolean Searching, Developing a Search Strategy

4. Database Searching, Deep Web

5. Website Evaluation, Domain Extensions

6. Plagiarism Prevention, Citation Styles, Paraphrasing, Quoting

7. Wrap-Up, Final Project Due, Posttest 
A final project is not a requirement of the workshop program, though most instructors assign a final project to tie the lessons learned in the course into an assignment. The final project serves to demonstrate what the students have learned in the course and also serves as a way to increase class participation and attendance in the workshop.

\section{THE Flipped Model}

The next academic year, two Library Competency Workshop classes, again, one in the Fall semester and the other in the spring semester, were taught using the flipped model. To flip this course, videos were created covering the material for that particular lesson. The videos were created using Camtasia Studio 7.0, using text captions instead of a voiceover. This decision was made by necessity as there was limited availability of quiet space to record the videos as they were being created. The videos were kept short, approximately 5 min each to keep student interest. Videos were assigned for the students to watch, as homework, for Weeks 2 through 6 of the course with an assignment to be completed after watching the video. Once in class, a more in depth and hands-on assignment was given for the students to complete, with the instructor available to assist students with the assignment in lieu of a typical lecture. For example, in the first class meeting, the students were told how the course would be run and were assigned a video on searching the library online catalog along with short catalog searching assignment. At the next class meeting, the students were given a lengthier assignment on using the catalog, which had them navigating the catalog as well as the book stacks to find materials. Four of the seven class meetings contained a flipped classroom video component.

\section{RESULTS}

\section{Pre- and Posttest Scores}

The final class session of all the sections consisted of course evaluations and the administering of the library competency exam again to assess changes from the scores of the exam taken in the first session. While there had been an increase from pre- to posttest scores in nonflipped sections, the increase was more pronounced in the flipped sections (see Figure 1). Pretest scores averaged in the mid to high 70s, on a 0-100 scale, for all of the sections tested whether flipped or not. Nonflipped courses showed a moderate increase in scores while the increase in scores in flipped section was more than double of that in the nonflipped sections, with flipped sections averaging $90 \%$ on the post tests. 


\begin{tabular}{|lccc|}
\hline Section & Pretest Score & Posttest Score & Change in Score \\
\hline Non Flipped (1) & $79 \%$ & $84 \%$ & $5 \%$ Increase \\
\hline Non-Flipped (2) & $72 \%$ & $78 \%$ & $6 \%$ Increase \\
\hline Flipped (1) & $75 \%$ & $90 \%$ & $15 \%$ Increase \\
\hline Flipped (2) & $78 \%$ & $90 \%$ & $12 \%$ Increase \\
\hline
\end{tabular}

FIGURE 1 Non-flipped vs. flipped class section test scores. Note. 20 students per section.

\section{Beyond the Scores}

There were some questions and trepidation about teaching such a short course in a flipped model given that there was very little class time to make any adjustments should anything unforeseen arise. So much of the success of the class and the study using the flipped model hinged on the students watching the videos as homework and coming to the class sessions prepared. A concern about the flipped model is how one can be sure that students are watching the videos before class? The same could be asked of classes that have assigned course readings, or any homework for that matter. In response, an additional homework activity that is based on the video was assigned and graded. Homework assignments were routinely handed in on time and students were prepared for the hands-on assignments in class. This was a very important aspect of the class that contributed significantly to its success and the success of the study.

Running the flipped model in the course also did succeed in making the Library Workshop Course feel and function more like a workshop. The sessions consisted of more hands-on and student centered activities and less lecture and demonstration. This left time for the instructor to take more questions from the students and more opportunity to assist them while they worked through the assignments in class and lent itself to opportunities for students to assist each other with the assignments.

An unanticipated, but very welcome, result of using the flipped model was observed with foreign students where the use and understanding of the English language could be a challenge. On a number of occasions it was observed that these students would watch the videos again in class while working in the assignment and pause the video to ask about certain words or terms that they did not understand.

\section{Limitations}

The study was limited in the number of sections, and overall students, that the flipped class could be taught in. The workshop course ran only a handful 
of sections per semester, which limits the number of sections any particular professor can teaching per semester, usually one at the most. This limited the study so that only two sections per academic year could be used in the study. The study should be expanded to include more sections instructed using the flipped model to gain more data to ascertain its instructional effectiveness.

Another limitation was the assessment measure that was used, the library competency exam. The exam, which was used as the assessment measure for this study, is the campuswide assessment used for the students to fulfil their Library Competency Requirement needed for graduation. The exam is a multiple-choice exam that lacks depth and the ability to gauge the students' practical use of their information literacy competency. A more in-depth and comprehensive assessment should be used to gain data that is more of a valid measure of the students' information literacy skills and comprehension.

\section{CONCLUSION}

Flipping one's classroom may seem like a novel idea, one that will pass like many educational fads of the past. Regardless, the main foundation of the concept is grounded in common teaching practice, having the students in the class actively engaged in the class as opposed to being passive note takers and lecture listeners. The flipped class model takes advantage of technology that is now available and easy to use for instructors, creating the content and making the lessons available to students on various platforms and course management systems.

The flipped classroom model in library instruction enhances a library instruction class by allowing instructors to devote the class time to the practice of research and, as indicated by the results of this study, increases students' posttest scores. Using the flipped classroom model for library instruction could be a very useful and potent tool for library instruction educators. Going forward, further studies could better assess if this improvement is standard by using statistical analysis with a much larger sample size.

\section{REFERENCES}

Arnold-Garza, S. (2014). The flipped classroom. College E Research Libraries News, $75,10-13$.

Bergmann, J., \& Sams, A. (2012). Flip your classroom: Reach every student in every class every day. Eugene, OR: International Society for Technology in Education. 
Datig, I., \& Ruswick, C. (2013). Four quick flips. College E Research Libraries News, 74, 249-257.

Khan, S. (2011, March). Salman Khan: Let's use video to reinvent education [Video]. Retrieved from http://www.ted.com/talks/salman_khan_let_s_use_ video_to_reinvent_education

Lemmer, C. A. (2013). A view from the flip side: Using the "inverted classroom" to enhance the legal information literacy of the international LL.M. student. Law Library Journal, 105, 461-491. 